\title{
EMBRYO CULTURE AND IN VITRO CLONAL PROPAGATION OF OAK
} (Quercus aegilops L.)

\author{
L. H. Fadladeen ${ }^{1}$ \\ Lecturer \\ R. S. Toma ${ }^{2}$ \\ Assist. Prof. \\ ${ }^{1}$ Dept. of Forestry, Coll. of Agric. Engin. Sci., University. of Duhok, Kurdistan Region of Iraq \\ ${ }^{2}$ Dept. of Hort., Coll. of Agric. Engin. Sci., University. of Duhok, Kurdistan Region of Iraq \\ laylan.fadladeen@uod.ac \\ rshtoma@uod.ac
}

\begin{abstract}
An attempt was done to develop a micropropagation protocol for oak using embryo culture. Oak is considered a hard-to-root woody plant by conventional propagation methods, that's why using tissue culture techniques is a very suitable alternative method. For oak embryo culture, WPM was used and found to be better than MS medium for embryo germination which gave $66.13 \%$. As well as adding of $\mathrm{GA}_{3}$ to the medium improved the germination rate of embryos $(43.25 \%$ and $82.25 \%)$. At initiation stage, WPM was used and found to be the best medium by giving the highest number of shoots/ explant which was 1.80 , the highest number of leaves (15.17 leaves/ explant) and the longest shoots $(1.42 \mathrm{~cm})$ followed by MS medium then GD which gave the lowest parameters which gave 0.98 shoots/ explant, 7.20 leaves/ explant and $1.06 \mathrm{~cm}$ shoot length. At shoot multiplication stage, BA was better than Kinetin for multiplication of oak explants. The addition of BA at 3 mg. $\mathrm{I}^{-1}$ gave the highest number of shoot and leaves which were 3.33 and 26.11 respectively. The longest shoots were achieved when $4.5 \mathrm{mg.l}^{-1}$ of BA was used. Furthermore, kinetin at 3 and $4.5 \mathrm{mg}^{-1}$ gave the lowest parameters which were $1 \mathrm{~cm}$ in length and 1.54 leaves/ explant. For rooting stage, NAA was better than IAA in giving better parameters and rooting percentage. The highest number of roots and rooting percentage were achieved when 1 mg. $l^{-1}$ was added by giving 6 roots/ explant and $100 \%$ rooting percentage. While the longest roots were achieved when $0.5 \mathrm{mg} . \mathrm{I}^{-1}$ of NAA was used $(3.67 \mathrm{~cm})$ followed by $1.5 \mathrm{mg} . \mathrm{I}^{-1}$ IAA which gave 3.55 roots/ explant with rooting percentage $90 \%$. The produced plantlets were successfully acclimatized and transferred to the open-air conditions with a rate reached $85 \%$.
\end{abstract}

Keywords: Oak, Quercus aegilops L., Micropropagation, Culture Media, Embryo Culture, Tissue culture.

*Part of PhD Dissertation of the $1^{\text {st }}$ author

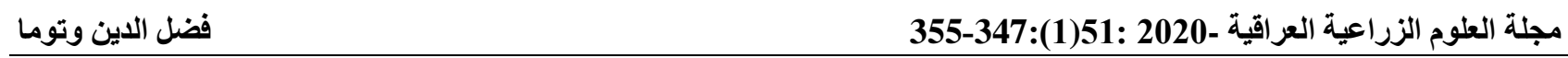

زراعة الأجنة والاكثار الاقيق خارج الجسم الحي للبلوط (1) (Quercus aegilops L)

\author{
روفائيل شليمون توما \\ أستاذ مساعد \\ قسم البستنة، كلبة علوم الهندسة الزراعية - جامعة دهوك
}

\author{
ليلان حسين فضل الدين \\ مدرس \\ قسم الغابات، كلية علوم الهندسة مساعد الزراعية -جامعة دهوك \\ المستخلص
}

تمت محاولة تطوير برنامج اكثار دقيق لنبات البلوط باستخام تقانة زراعة الأجنة. يعتبر البلوط من النباتات الخشبية الصعبة التجذير من خلال الطرق

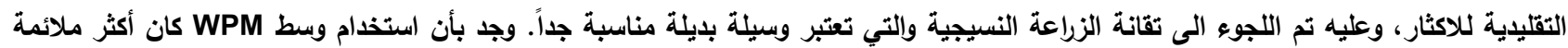
من استخدام وسط MS في انبات الأجنة والذي أعطى نسبة انبات 666.13\%. كذلك فإن اضافة حامض الجبرليك الى وسط الزراعة قد حَسَّن من نسبة

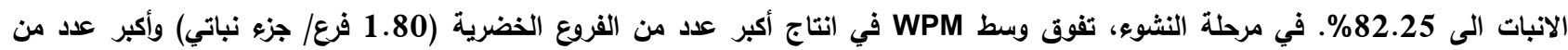

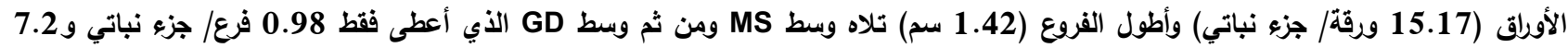

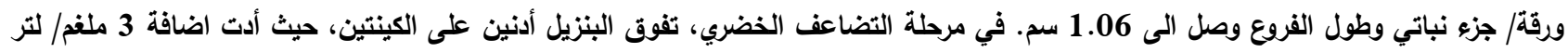

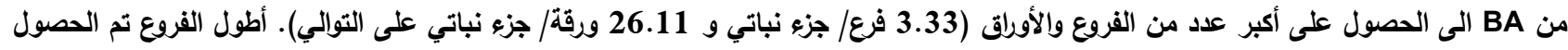

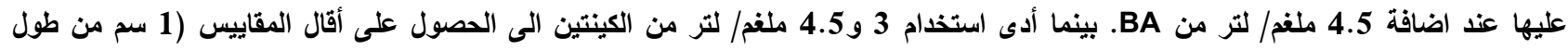

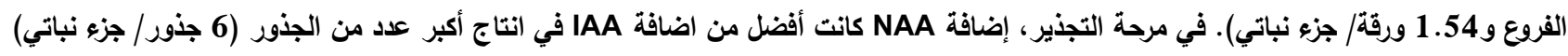

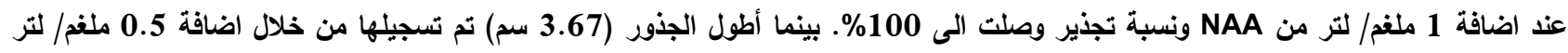

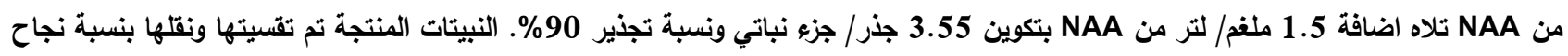
وصلت الى 85\% الى ظروف الحقل الخارجي. 


\section{INTRODUCTION}

Quercus aegilops belongs to the Fagaceae family and the Fagales genus which is one of the most important genera in the Mediterranean forest. It is one of the most widespread oak species present naturally in the Kurdistan Mountains, estimated to account for as much as $70 \%$ of the total Oak area (19). Oak is commercially propagated only by seeds because of graft incompatibility and the fact that vegetative cuttings are almost impossible to root (16). Most of the other oak species are also recalcitrant to vegetative propagation (18). Embryo dormancy and immaturity problems have been reported in many local nurseries in the region. Furthermore, trees require long periods of time to reach reproductive maturity and there are no efficient methods for the vegetative propagation of oak species (6). For these reasons, in vitro propagation could be an attractive alternative to solve these problems and to allow the rapid multiplication of Valonia oak. This technique is effective because almost all plant cells are totipotent and each cell possesses the genetic information and cellular machinery necessary to generate an entire organism. Micropropagation, therefore, can be used to produce a large number of plants that are genetically identical to the mother plant, as well as to one another (15). Based on the lack of research on application of tissue culture techniques on $Q$. aegilops species, the main objectives of the study are: Establishing a simple tissue culture protocol for vegetative propagation of $Q$. aegilops in order to protect this species from disappearing and to produce enough planting stocks for reforestation of damaged oak areas as well as achieving a protocol for embryo culture to overcome embryo dormancy and seed immaturity problems. Embryo culture is one of the earliest forms of in vitro culture applied to practical problems and is probably the tissue culture technique that has proven of greatest value to breeders (7). Its major application in plant breeding has been for interspecific hybridization. Different methods such as heating (9), stratification, scarification (13) and gibberellin application are well known to overcome these problems depending on the type of plant species and dormancy.
Moist chilling or cold stratification is widely used for breaking seed dormancy and increasing the rate of germination percentage of dormant seeds of many species (23). Influence of various concentrations of growth substances in seed germination and seedling growth was reported by (5). The period of stratification treatment is very important and differs from one species to another; for example, (25) used $4 \pm 2{ }^{\circ} \mathrm{C}$ for, 10,15 and 20 days for cold stratification of Quercus glauca Thunb. They reported that among the treatments, the stratification for 15 days was found to be the most effective in breaking seed dormancy in Quercus glauca seeds, achieving $95.45 \%$ germination. Gibberellins (GAs) are plant hormones that regulate various developmental processes, including stem elongation, embryo germination, dormancy, flowering, flower development and leaf and fruit senescence (8). The addition of cytokinins to the culture medium is very important because it is the base of shoot proliferation and shoot morphogenesis. The literature review has shown that the cytokinin most widely used in the multiplication stage of plant micropropagation is BA, followed by kinetin (2). In general, in the case of $Q$. spp, it has been shown that WPM is the most suitable medium for the multiplication stage, followed by GD medium and then MS medium, also that BA is the most suitable cytokinin (16). At rooting stage, auxins are usually used for adventitious root formation. Generally, when the concentration of auxin is low, root formation is favored; and when the concentration is high, callus formation occurs. Published researches suggested that the addition of auxins is essential for in vitro oak rooting (22 and 14).The current study was aimed to improve a micropropagation protocol for this important forest tree from explants grown from embryo culture by testing various culture media and different plant growth regulators.

\section{MATERIALS AND METHODS}

Mature acorns of $Q$. aegilops were collected from wild trees growing on Gara Mountain at the end of October and beginning of November. Only healthy acorns without apparent damage caused by insects were selected. Because of the limited quantity of 
viable and sound acorns, the acorns from all trees were pooled and used for experimentation. For stratification, oak acorns were thoroughly washed with running tap water to remove dust and soil and then stored in the refrigerator at $5^{\circ} \mathrm{C}$. Stratification testing was conducted after $(1,2,3$ or 4$)$ weeks of storage. Once the acorns were separated from the cupules they were rinsed vigorously under running tap water and washed three times with liquid detergent. Next, the seed coats were removed from the acorns and the intact embryos were collected and grouped for sterilization experiments. The embryos were transferred to the Laminar air flow cabinet for the next sterilization step in which they were treated with $70 \%$ ethanol alcohol for 30 seconds followed by three rinses with sterilized distilled water each for 3 minutes. After that, the embryos were treated with sodium hypochlorite $(\mathrm{NaOCl})$ at 15,30 or 45 $\%$ and 2 drops of Tween-20 for three periods of 1,3 or 5 minutes. Subsequently, they were rinsed with sterilized distilled water three times each for 3 minutes. Finally, the ends of the explants that were exposed to sterilants on the plomule side were trimmed and the embryos were cultured on MS and WPM media supplemented with $0,0.5 \mathrm{mg}^{-1} \mathrm{GA}_{3}$. A month later, the germination percentage was calculated and the explants were used for the micropropagation experiment. From in vitro germinated embryos, $1 \mathrm{~cm}$ long nodes were taken for starting a micropropagation protocol. At initiation stage, three types of culture media were tested (MS, WPM or GD), supplemented with $0,1,2,3$, or $4 \mathrm{mg}^{-1} \mathrm{BA}$ and $\mathrm{GA}_{3}$ at 0,1 $\mathrm{mg}^{-1}$. To avoid contact with excreted phenolic compounds, each explant was moved to the opposite side of its culture and then to other fresh medium at one and two days after the initiation of culture; thereafter, the explants were transferred to fresh initial medium every 3 weeks. After 8 weeks of culture, the parameters were recorded and the microshoots were cut off and cultured on multiplication medium. At multiplication stage the best performing medium from the initiation stage was used, supplemented with two kinds of cytokinins, BA or Kinetin at $0,1.5,3$ or 4.5 $\mathrm{mgl}^{-1}$. Then the explants were transferred to fresh multiplication medium every 3 weeks.
After 8 weeks of culture, the parameters were recorded as mean number of shoots per explant, number of leaves per explant and the mean length of shoots. Then the microshoots were transferred to the rooting stage. At the rooting stage, the microshoots were cultured on MS and WPM media full salt strength supplemented with NAA and IAA at $0,0.5,1$, 1.5 or $2 \mathrm{mgl}^{-1}$. To avoid contact with excreted phenolics, each microshoot was moved to the opposite side of its culture and then to other fresh medium after one and two days of culturing on rooting medium; thereafter, the micro shoots were transferred to fresh rooting medium every 3 weeks. After 8 weeks on rooting medium the mean number of roots per microshoot and the mean root length parameters were recorded. The rooted plantlets were taken from the rooting medium and washed thoroughly with water to remove adhering medium and then immersed in a beaker containing $1.8 \mathrm{gml}^{-1}$ beltanol fungicide for 10 minutes and then washed with distilled water, after which the rooted plantlets were transferred to pots containing autoclaved peatmoss, loam and Styrofoam (1:1:0.5) (v:v:v) (21). The pots were placed in a sterilized box under a polyethylene cover and during the first week the plantlets were foliar sprayed with quarter strength WPM salts as needed and in the second week the plastic cover was poured and then removed.

\section{RESULTS AND DISCUSSION}

The results of the current study indicate the possibility of micropropagation of this difficult-to-root forest tree. The recorded parameters showed significant statistical differences as treated with various experimental tested factors. For achieving an aseptic healthy embryo culture, a disinfestation experiment was applied. Figure (1) shows the effect of different concentrations of sodium hypochlorite in different periods of time on embryo explants. The results showed that the highest rates of healthy aseptic cultures $(100 \%)$ were achieved from treatments $30 \%$ for 5 minutes and $45 \%$ for 1,3 or 5 minutes sodium hypochlorite but the latter three treatments caused a notable damage to the culture tissues and the embryos didn't germinate. Therefore the first treatment was selected for disinfesting the explants for later 
experiments. As it is known that the minimum concentration and duration of sterilants treatment is more preferable to insure not damage to the treated explants (17). Sodium hypochlorite is always proving to be the best sterilant ever being effective not only as decontaminant but also easy to remove from explants with a minimal damage to the explant tissue.

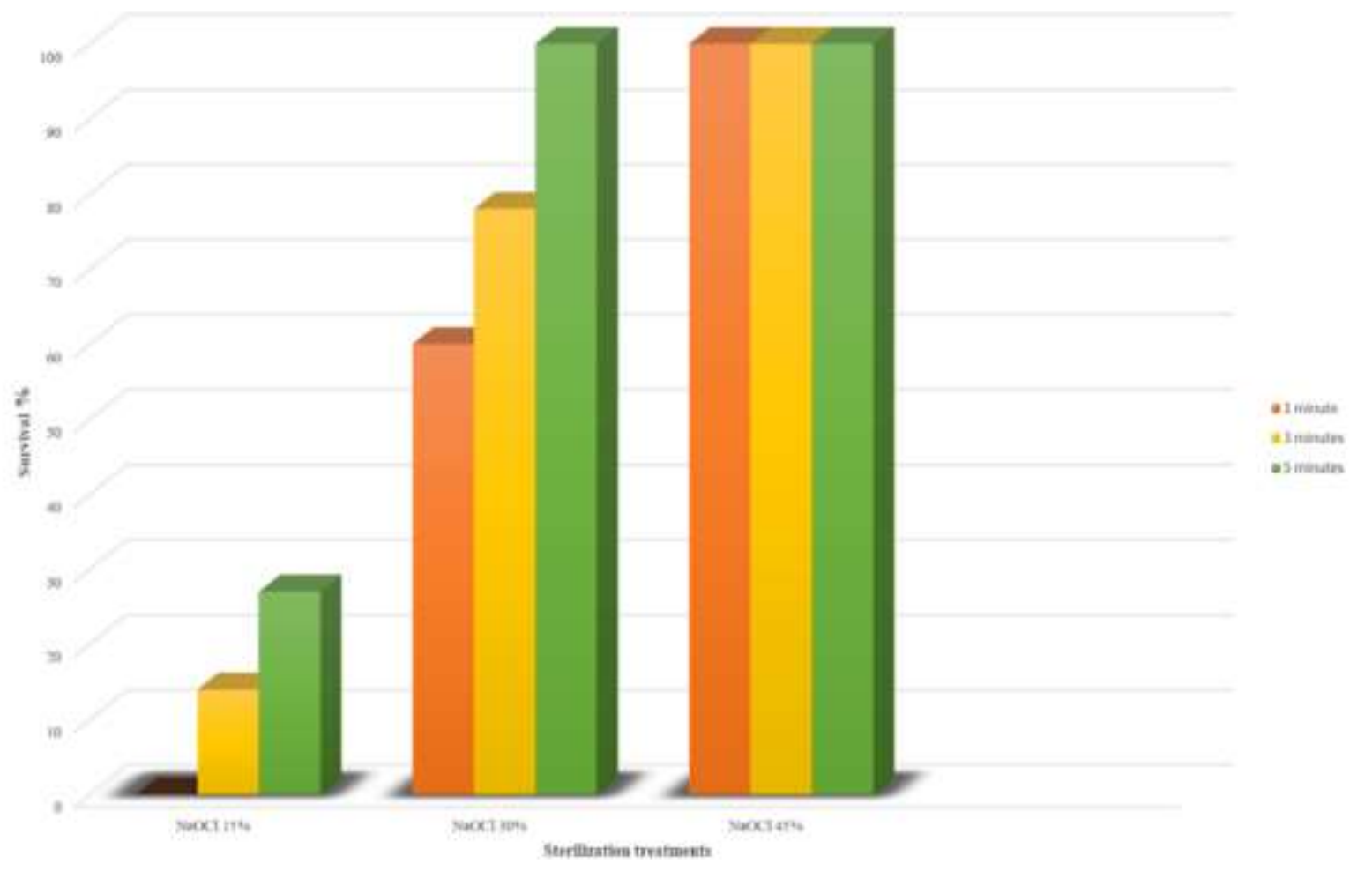

Figure (1): Embryo Sterilization by testing different sodium hypochlorite concentrations and treatment durations

Table 1 illustrates the effect of two media (MS and WPM) with two concentrations of $\mathrm{GA}_{3} 0$ or $0.5 \mathrm{mg} . \mathrm{l}^{-1}$ in four stratification periods 1,2 , 3 or 4 weeks. It is clear that WPM was better than MS medium for embryo germination which gave $66.13 \%$. As well as adding of $\mathrm{GA}_{3}$ to the medium improved the germination rate of embryos (43.25\% and $82.25 \%$ ). On the other hand the germination rate increased during stratification period and the best stratification period was 2 weeks then after that the rate was decreased. Similar results have been recorded by (14) during the propagation of $Q$. serrate and $Q$. semecarpifolia. The highest germination rate $(100 \%)$ was achieved from the use of WPM supplemented with $0.5 \mathrm{mg} . \mathrm{l}^{-1} \mathrm{GA}_{3}$ and after two weeks of stratification followed by the same medium and hormone concentration but after one and three weeks of stratification which gave $86 \%$ germination rate (Figure 2).

Table 1. Effect of $\mathrm{GA}_{3}$ and stratification periods on oak embryo germination rate

\begin{tabular}{|c|c|c|c|c|c|c|c|}
\hline \multirow[b]{2}{*}{ Medium } & \multirow{2}{*}{ 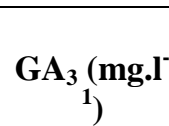 } & \multicolumn{4}{|c|}{ Germination Rate (\%) } & \multirow[b]{2}{*}{$\mathbf{G A}_{3}$} & \multirow{2}{*}{$\begin{array}{c}\text { Culture } \\
\text { Media }\end{array}$} \\
\hline & & 1 & atificat & d $(w$ & 4 & & \\
\hline \multirow{2}{*}{ MS } & 0.0 & $28 \mathrm{e}$ & $43 \mathrm{~d}$ & $43 d$ & $28 \mathrm{e}$ & $35.5 \mathrm{c}$ & \multirow{2}{*}{$39.38 \mathrm{~b}$} \\
\hline & 0.5 & $30 \mathrm{e}$ & $57 \mathrm{c}$ & $43 \mathrm{~d}$ & $43 \mathrm{~d}$ & $43.25 \mathrm{~b}$ & \\
\hline \multirow{2}{*}{ WPM } & $\mathbf{0 . 0}$ & $57 \mathrm{c}$ & $57 \mathrm{c}$ & $43 \mathrm{~d}$ & $43 \mathrm{~d}$ & 50 b & \multirow{2}{*}{$66.13 \mathrm{a}$} \\
\hline & 0.5 & $86 \mathrm{~b}$ & 100 a & $86 \mathrm{~b}$ & $57 \mathrm{c}$ & $82.25 \mathrm{a}$ & \\
\hline
\end{tabular}




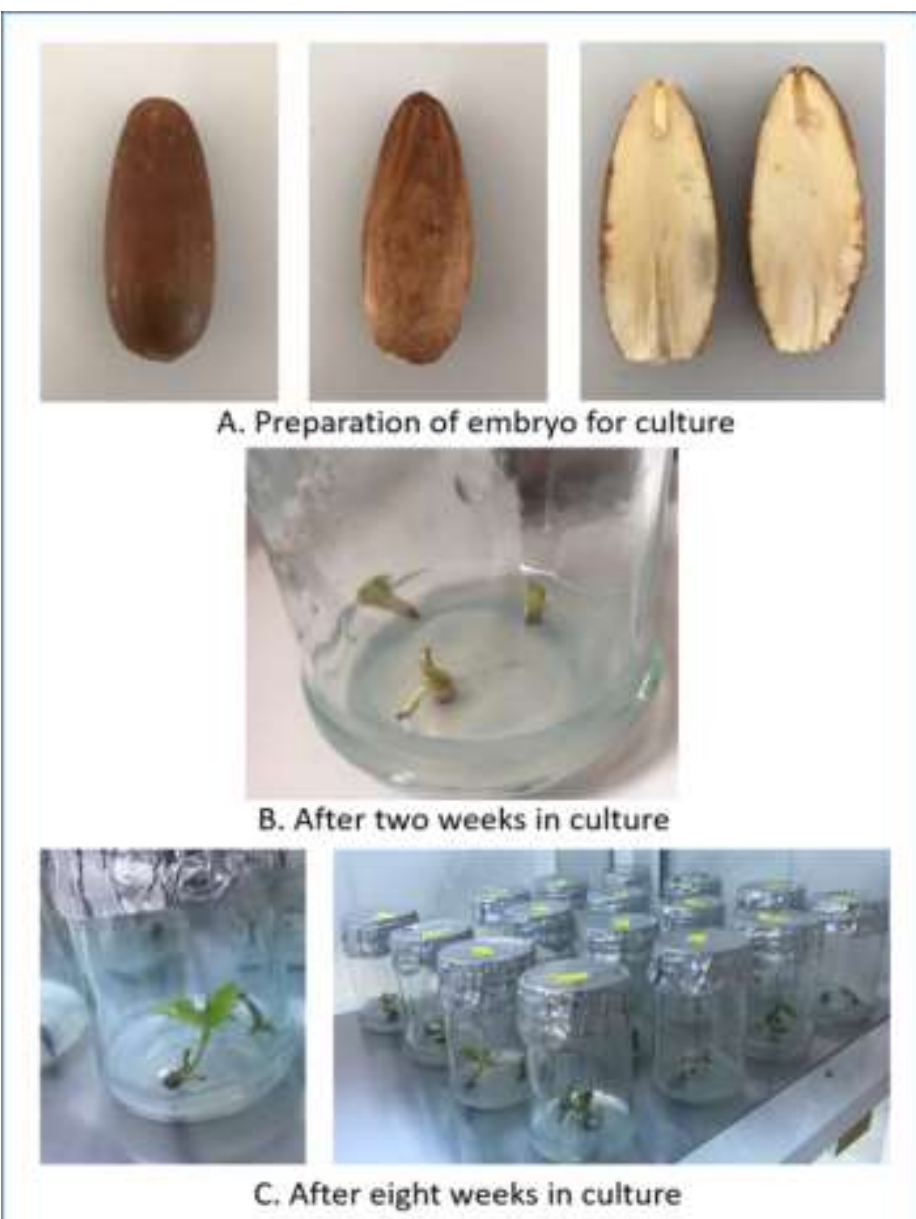

Figure (2): Oak embryo preparation and culture

Table 2 illustrates the effect of the three culture media, BA at different concentrations $(0,1,2,3$ or 4$) \mathrm{mg} \cdot \mathrm{l}^{-1}$ and $\mathrm{GA}_{3}$ at 0 or $1 \mathrm{mg} \cdot \mathrm{l}^{-1}$ on initiation stage of $Q$. aegilops after eight weeks of culture. In general, among the three media, WPM was the best medium by giving the highest number of shoots/ explant which was 1.80 , the highest number of leaves $(15.17$ leaves/ explant) and the longest shoots (1.42 $\mathrm{cm}$ ) followed by MS medium then GD which gave the lowest parameters which gave 0.98 shoots/ explant, 7.20 leaves/ explant and 1.06 $\mathrm{cm}$ shoot length. Similar results were published by (2, 4, 18, 16, 22 and 24). Nevertheless, the absence of $\mathrm{GA}_{3}$ in the medium gave the best results which were 1.57 shoot, 13.10 leaves and $1.52 \mathrm{~cm}$ length (Figure 3). Accordingly, 3 and $4 \mathrm{mg} \cdot \mathrm{l}^{-1} \mathrm{BA}$ were the best treatments in giving the highest number of shoots (1.6 and 1.7 respectively) as well as BA at $3 \mathrm{mg} .1^{-1}$ gave the highest number of leaves (11.80 leaves/ explant). However, 2 and 4 mg. $1^{-1}$ of BA gave the longest shoots (1.63 and $1.60 \mathrm{~cm}$ ) respectively. It is clear that the interaction between the media and the growth regulators gave best results for instance, the highest number of shoots and leaves were achieved when WPM was supplemented with 3 and $4 \mathrm{mg} \cdot \mathrm{l}^{-1} \mathrm{BA}$ and $0 \mathrm{mg} \cdot \mathrm{l}^{-1} \mathrm{GA}_{3}$ by giving 3 shoots/ explant and 26 leaves/ explant while MS medium supplemented with $2 \mathrm{mg} . \mathrm{l}^{-1}$ and 0 mg. $1^{-1} \mathrm{GA}_{3}$ gave the longest shoots which was $2.4 \mathrm{~cm}$. Similar results were recorded by (10). Moreover, GD medium free of growth regulators gave the lowest parameters where the explants were not grown at all. 
Table 2. Effect of BA on culture initiation stage of oak explants grown on different culture media with and without $\mathrm{GA}_{3}$ after eight weeks in culture

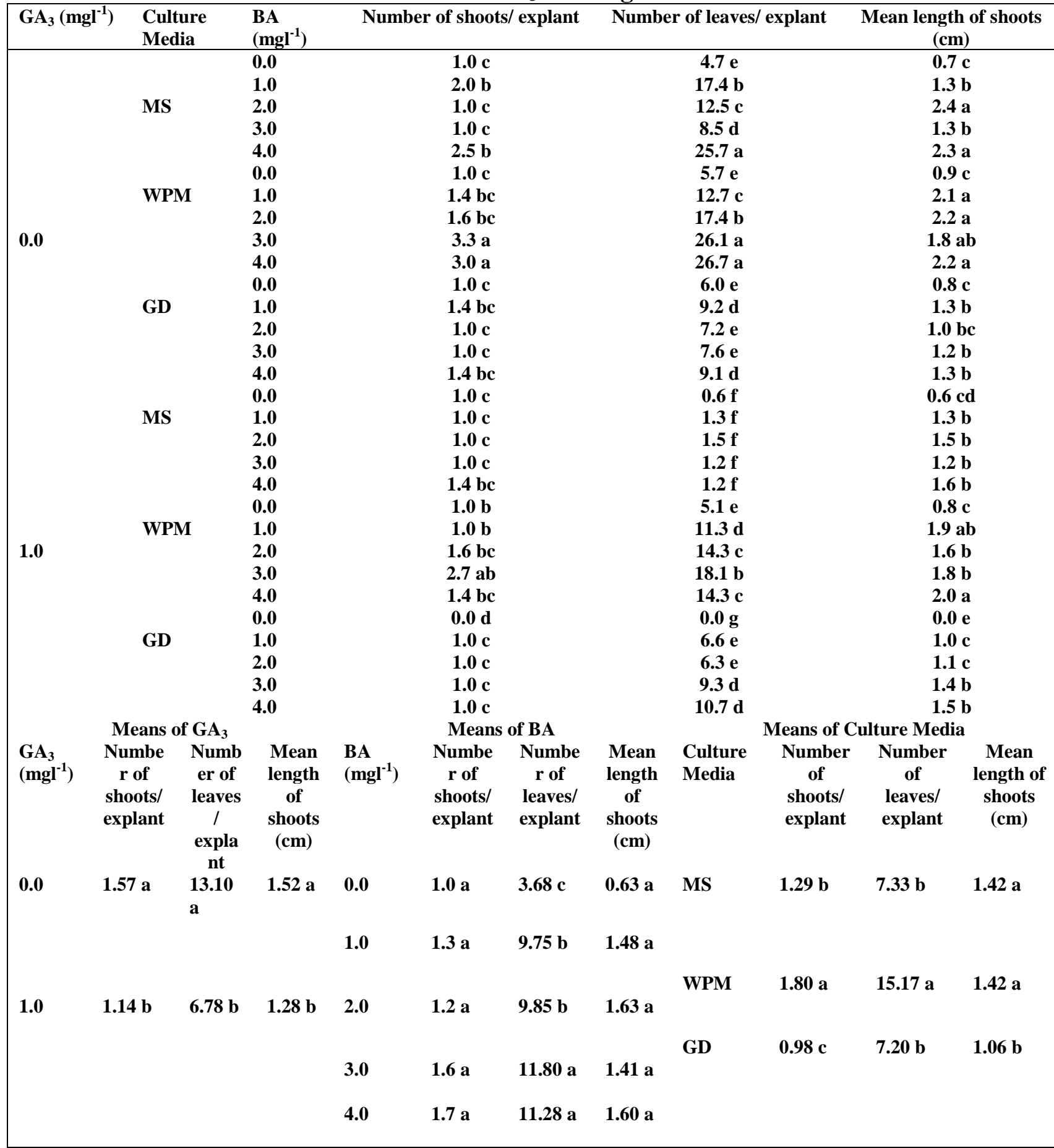

Table 3 shows the effect of BA or Kinetin with same concentration $(0,1.5,3$ or 4.5$) \mathrm{mgl}^{-1}$ on the multiplication of $O$. aegilops shoot grown on the best initiation medium (WPM) after eight weeks of culturing. Overall, BA was better than Kinetin for multiplication of oak explants as many researcher published as $(4$, $10,16,18,22$ and 24) where BA at $3 \mathrm{mg} .1^{-1}$ gave the highest number of shoot and leaves which were 3.33 and 26.11 respectively. Similar result were reported by Leon et al. (2013) while the longest shoots were achieved when $4.5 \mathrm{mg} . \mathrm{l}^{-1}$ of BA was used $(2.83 \mathrm{~cm})$. Furthermore, kinetin at 3 and $4.5 \mathrm{mg}^{-1}$ gave the lowest parameters which were $1 \mathrm{~cm}$ in length and 1.54 leaves/ explant. 
Table 3. Effect of BA and Kinetin on shoot multiplication stage of oak explants grown on WPM after eight weeks in culture

\begin{tabular}{|c|c|c|c|c|}
\hline \multicolumn{2}{|c|}{ Cytokinins (mg.l $\left.{ }^{-1}\right)$} & $\begin{array}{c}\begin{array}{c}\text { Number of shoots/ } \\
\text { explant }\end{array} \\
\end{array}$ & $\begin{array}{c}\text { Number of leaves/ } \\
\text { explant }\end{array}$ & $\begin{array}{c}\text { Mean length of shoots } \\
(\mathrm{cm})\end{array}$ \\
\hline $\mathbf{0 . 0}$ & & $1.0 \mathrm{~d}$ & $6.44 \mathrm{c}$ & $1.01 \mathrm{c}$ \\
\hline & 1.5 & $1.88 \mathrm{~b}$ & $17.44 \mathrm{~b}$ & $2.02 \mathrm{~b}$ \\
\hline \multirow[t]{3}{*}{$\mathbf{B A}$} & 3.0 & $3.33 \mathrm{a}$ & 26.11 a & $1.86 \mathrm{~b}$ \\
\hline & 4.5 & $2.11 \mathrm{~b}$ & 24.22 a & $2.83 \mathrm{a}$ \\
\hline & 1.5 & $1.0 \mathrm{~d}$ & $6.44 \mathrm{c}$ & $1.01 \mathrm{c}$ \\
\hline \multirow[t]{2}{*}{ Kinetin } & 3.0 & $1.0 \mathrm{~d}$ & $6.33 \mathrm{c}$ & $1.0 \mathrm{c}$ \\
\hline & 4.5 & $1.55 \mathrm{c}$ & $1.54 \mathrm{~d}$ & $1.65 \mathrm{~b}$ \\
\hline
\end{tabular}

Table 4 shows the effect of two auxins (NAA and IAA) on rooting stage of $Q$. aegilops microshoots grown on WPM with full salt strength after eight weeks of culture. In general, NAA was better than IAA in giving better parameters and rooting percentage. The highest number of roots and rooting percentage were achieved when $1 \mathrm{mg} .1^{-1}$ was used by giving 6 roots/ explant and 100\% rooting percentage. While the longest roots were achieved when $0.5 \mathrm{mg} .1^{-1}$ of NAA was used $(3.67 \mathrm{~cm})$ followed by $1.5 \mathrm{mg}^{-1} \mathrm{l}^{-1}$ IAA which gave 3.55 roots/ explant with rooting percentage $90 \%$. On the other hand, the lowest number of roots and rooting percentage were achieved at control treatment and $0.5 \mathrm{mg} . \mathrm{l}^{-1}$ IAA treatments while the shortest roots were achieved $(2.10 \mathrm{~cm})$ when $2 \mathrm{mg} . \mathrm{l}^{-1}$ IAA was used. Finally, the healthy produced oak plantlets were gradually moved from the lab into out-air conditions with a successful rate reached $85 \%>$

Table 4. Effect of IAA and NAA on root formation stage of oak microshoots grown on WPM after eight weeks in culture

\begin{tabular}{|c|c|c|c|c|}
\hline \multicolumn{2}{|c|}{ Auxins (mg. $\left.\mathrm{l}^{-1}\right)$} & Number of roots/ explant & Mean length of roots $(\mathrm{cm})$ & Rooting Percentage (\%) \\
\hline \multirow[t]{2}{*}{0.0} & & $1.11 \mathrm{~d}$ & $2.95 \mathrm{~b}$ & 70 \\
\hline & 0.5 & $1.11 \mathrm{~d}$ & $3.50 \mathrm{a}$ & 70 \\
\hline \multirow[t]{4}{*}{ IAA } & 1.0 & $2.55 \mathrm{c}$ & $2.89 \mathrm{~b}$ & 85 \\
\hline & 1.5 & $3.55 \mathrm{~b}$ & $2.99 \mathrm{~b}$ & 90 \\
\hline & 2.0 & $2.11 \mathrm{c}$ & $2.10 \mathrm{c}$ & 90 \\
\hline & 0.5 & $3.44 \mathrm{~b}$ & $3.67 \mathrm{a}$ & 90 \\
\hline \multirow[t]{3}{*}{ NAA } & 1.0 & $6.00 \mathrm{a}$ & $3.01 \mathrm{~b}$ & 100 \\
\hline & 1.5 & $2.88 \mathrm{c}$ & $3.05 \mathrm{~b}$ & 90 \\
\hline & 2.0 & $2.66 \mathrm{c}$ & $2.98 \mathrm{~b}$ & 90 \\
\hline
\end{tabular}

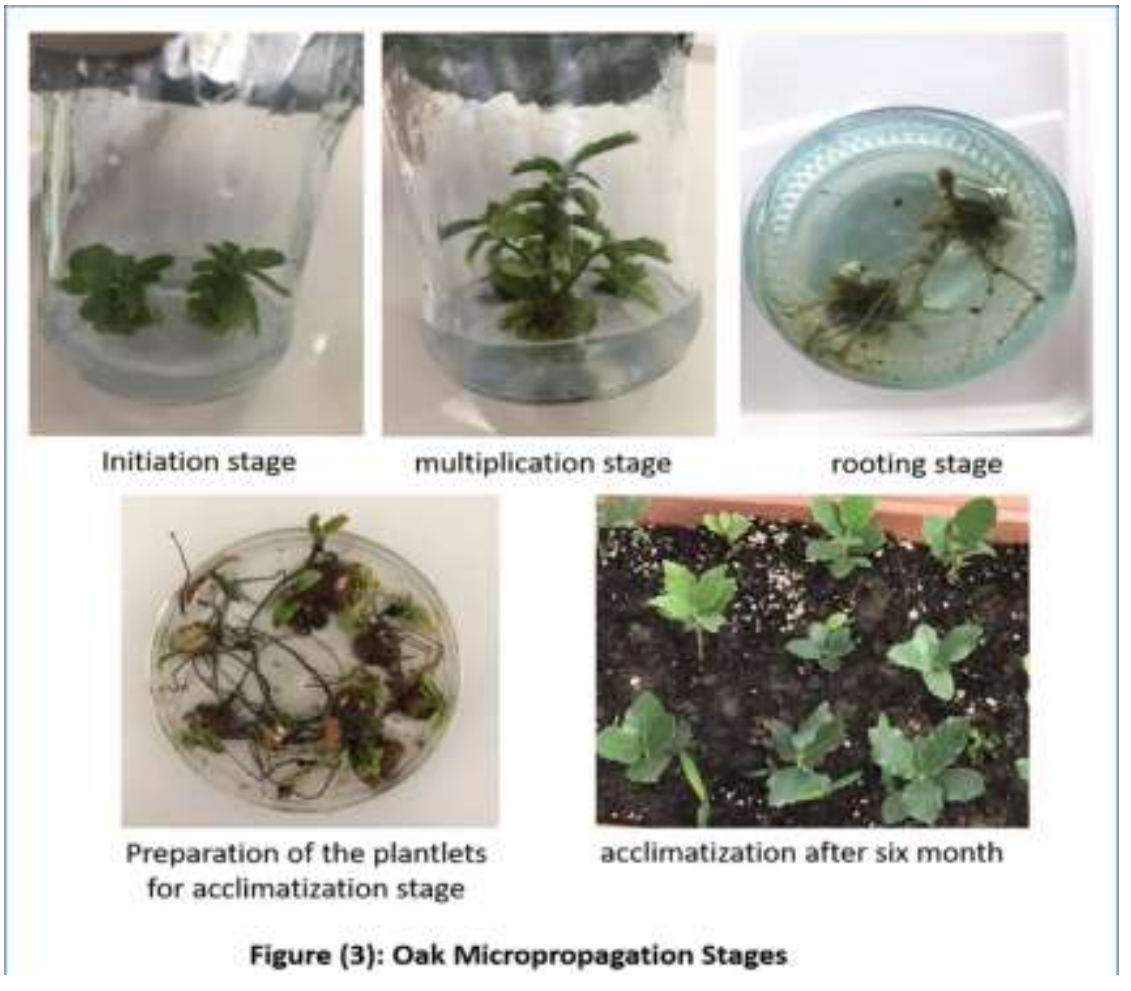


The enhancing role of cytokinins on plant shoot multiplication is greatly due to their high effects in releasing lateral and axillary buds from the apical dominance of terminal buds without the need to cut-off the apical bud by promoting the formation of xylem and phloem tissues of buds which facilitate the transformation of nutrients and water leading to non-terminated buds growth (12). Beside to their great role in biosynthesis of RNA, enzymes and proteins in the plant cell which enhance bud growth too (1). Furthermore, the genetic plant organ structure has an effect on the response of cultured explant because of its influence on endogenous hormone content (20). The overall conclusion drawn from shoot multiplication results is that Kinetin was less effective than BA at the same concentrations on shoot multiplication of apple and pear cultivars. The reasons behind BA superiority might be due to its molecular structure and the number of double bonds on its side chain of benzyl ring (11). In addition, BA is the most effective cytokinin in cell division and overcome apical dominance as compared to other cytokinins (3). Regarding root formation stage, the results of the current study proved prominent role of NAA in enhancing rooting process since it promotes adventitious roots initiation on the bases of cultured shoots (21). The different results achieved from growing on various culture media is due to the different composition of macronutrients, micronutrients, vitamins and other organic compounds which vary according to the plant species. However, for specific plant species and based on type of explant. In conclusion, it can be said that through applying the results of this study for micropropagation of oak to approach mass production in low cost programs.

\section{REFERENCES}

1. Al-Rifae'e, M. A. T. and S. A. Al-Shobaki. 2002. Twenty one century techniques for plant improvement by tissue culture. Cairo: Dar AlFikr Al-Arabi. (In Arabic).

2. Barlass, M. and Skene 1982. In vitro plant formation from Citrus species and Hybrids. Sci. Hort. 17: 333-341

3. Bashi, A. Z. Q. 2006. Promotion of embryos growth for in vitro cultured seeds of local Citrus limon L. Brum. F. Raf. Agricult. J., 34(2) 13-20
4. Chalupa, V., 1993. Vegetative propagation of oak (Quercus robur and Q. petraea) by cutting and tissue culture. Ann. Sci. For., 501: 295-307

5. Dhoran, V.S. and S. P.Gudadhe, 2012. Effect of Plant Growth Regulators on Seed Germination and Seedling Vigour in Asparagus sprengeri Regelin. In. Res. J. Bio. Sci. 1(7):6-10

6. Diaz-Pontones, D. and I. Reyes-Jaramillo, (2009). Production and acclimatization of Quercus hintonii Warburg (Fagaceae). Botan. J. 27: 131-143

7. Dunwell, J. M. 1986. Pollen, ovule and embryo culture as tools in plant breeding, $p$. 375-404. In: L.A. Withers and P.G. Alderson (eds.). Plant tissue culture and its agricultural applications. Butterworths, London

8. Hedden, P. and V. Sponsel, 2015. Acentury of Gibberellin research. J. of Plant Growth Regulation. 34 (4): 740-60

9. Herranz, J. M.; P. Ferrandis, and J. J. Martínez Sánchez, 1999. Influence of Heat on Seed Germination of Nine Woody Cistaceae Species. Int. J. Wildl. Fire, 9:173-182

10. León, J. S. D.; J. F. Morales-Domínguez; M. S. Santos-Díaz, and E. P.Molphe-Balch, 2013. In vitro propagation of Mexican oaks (Quercus spp.). Num. ISSN 1405-2769. 35: 85-97

11. Mohammed, A. K. 1985. Plant Physiology. $2^{\text {nd }}$ Part. Ministry of Higher Education and Scientific Research, University of Mosul, Iraq. (In Arabic).

12. Mohammed, A. K and M. A. Al-Younis,. 1991. Fundamentals of Plant Physiology ( $3^{\text {rd }}$ Part). College of Agriculture, Baghdad University, Iraq. (In Arabic).

13. Narbona, E.; M. Arista, and P. L. Ortiz, 2003. Seed germination of Arbutus unedo L. (Ericaceae). Acta Bot. Mala, 28:73-78

14. Pandey, A. and S. Tamta, 2014. In vitro propagation of the important tasar oak (Quercus serrata thumb.) by casein hydrolysate promoted high frequency shoot proliferation. J. of Sustain. Forest. 33: 590-603 15. Preesman, 2005. Roskam Young plants. (www.roskam-youngplants.com),

(www.preesman.com).

16. Purohit, V. K.; L. M. S.; Palni, S. K. Nandi, and H. C. Rikhari, 2002. In vitro regeneration of Quercus fl oribunda Lindl. through cotyledonary nodes: an important tree 
of Central Himalaya. Current Sci., 833: 312316

17. Razdan, M. K. 2003. Introduction to plant tissue culture. $2^{\text {nd }}$ ed. Science Publishers. INC 18. Sanchez, M. C.; M. C.; San-José, A. Ballester, and A. M. Vieitez, 1996. Requirements for in vitro rooting of Quercus robur and Quercus rubra shoots derived from mature trees, Tree Physiol. 16: 673-680

19. Shahbaz, S. E. 2010. Tree and shrubs afield guide to the trees and shrubs of Kurdistan Region of Iraq. First edition, University of Duhok publication. No. 2232/12/2009

20. Singh, S., B. K. Ray, S. Bathttcharryya and P. C. Deka 1994. In vitro propagation Skirvi., R. M. 1984. The tissue culture of stone fruits In: Handbook of plant cell culture. Vol.3 Crop Science.

21. Toma R. S., G. H. Daniel and A. N. Y. Habash, 2012. In vitro morphogenetic response of apple (Malus domestica Borkh.) and pear (Pyrus communis L.) to the elevated levels of copper and myo-inositol. ACTA AGROBOTANICA Vol. 65 (3): 43-48

22. Vengadesan, G. and P. M. Pijut, 2009. In vitro propagation of northern red oak (Quercus rubra L.). In Vitro Cell. Dev. Biol-Plant, 45: 474-482

23. Wang, B. S. P. and P. Berjak, 2000. Beneficial Effects of Moist Chilling on the Seeds of Black Spruce (Picea mariana [Mill.] B.S.P.). Ann. Bot., 86(1):29-36. doi: 10.1006/ anbo. 2000.1150

24. Wesoly, W.; M.; Hauke, W. Lassocinski; and A. Olszewska, 2004. Micropropagation of oaks from seedling fragments. Acta. Sci. Pol. Silv. Colendar. Rat. Ind. Lignar. 3(1): 51-62.

25. Zulfiqar; Mulk S. Khan, and H. Ahmad, 2015. Effect of pre-sowing treatments on seed germination in Quercus glauca Thunb., collected from different sampling sites of the Himalayan region of Pakistan. In. J. of Bioscie. Vol: 6, No. 11. pp: 42-48. 